\title{
Bacterial Community Characteristics and Enzyme Activities in Bothriochloa ischaemum Litter Over Progressive Phytoremediation Years in a Copper Tailings Dam
}

OPEN ACCESS

Edited by:

Qiaoyun Huang, Huazhong Agricultural University,

China

Reviewed by:

Guy Lanza,

SUNY College of Environmental Science and Forestry, United States Michaeline B. N. Albright, Los Alamos National Laboratory

(DOE), United States

${ }^{*}$ Correspondence:

Tong Jia

jiatong@sxu.edu.cn

†These authors have contributed equally to this work

Specialty section: This article was submitted to

Microbiotechnology,

a section of the journal

Frontiers in Microbiology

Received: 26 May 2020 Accepted: 03 December 2020

Published: 21 December 2020

Citation:

Jia T, Wang Y and Chai B (2020) Bacterial Community Characteristics and Enzyme Activities in Bothriochloa ischaemum Litter Over Progressive Phytoremediation Years in a Copper

Tailings Dam.

Front. Microbiol. 11:565806. doi: 10.3389/fmicb.2020.565806

\section{Tong Jia ${ }^{* t}$, Yuwen Wang ${ }^{\dagger}$ and Baofeng Chai}

Shanxi Key Laboratory of Ecological Restoration on Loess Plateau, Institute of Loess Plateau, Shanxi University, Taiyuan, China

Litter decomposition is the key link between material circulation and energy flow in ecosystems, resulting from the activity of resident microbes and various enzymes. This study investigated enzyme activity in litter and associated microbial community characteristics to help clarify the internal mechanisms associated with litter decomposition, while also providing researchers a scientific basis for soil remediation in mining areas. Results confirmed that the nutrient content of Bothriochloa ischaemum litter significantly increased as phytoremediation years progressed, while enzyme activities in litter varied over different phytoremediation years. During the litter decomposition process, cellulase predominated in the early phytoremediation stage and catalase predominated in the intermediate phytoremediation stage. Obvious differences were found in bacterial community structure and diversity over progressive phytoremediation years. Predominant bacterial genera mainly included Massilia, Sphingomonas, Curtobacterium, Amnibacterium, and Methylobacterium. Moreover, Methylorosula and Jatrophihabitans had relatively higher betweenness centrality, and played important roles in bacterial community positive interactions. Additionally, total nitrogen (TN) and total zinc in soil, sucrase and catalase activity in litter were the main environmental factors that affected the structural framework of bacteria in $B$. ischaemum litter. However, TN had the greatest overall effect on the structural framework of bacteria in litter. Results from this study can help our understanding of the role that litter plays in degraded ecosystems. Our results also provide a scientific basis for improving poor quality soil in areas affected by copper tailings while also amending ecological restoration efficiency.

Keywords: copper tailings, Bothriochloa ischaemum, litter, bacterial community, enzyme activities

\section{INTRODUCTION}

Litter is a crucial source of organic matter and nutrient elements in ecosystems, while litter decomposition plays an important role in ecosystem material circulation and energy flow (Song et al., 2014; Müller et al., 2016). Although litter decomposition is mainly driven by microorganisms (Crumsey et al., 2015), enzymes also play a critical role. Microorganisms affect litter decomposition 
by producing and optimizing enzymatic distribution (Ostaszewski and Nissen, 1988) while concurrently effecting soil properties. The production of extracellular enzymes depends on the type of microorganism and its nutritional requirements, and such production typically reflects the dynamics of litter degradation. In a study on forest litter in a northern subtropical latitude, urease and cellulase were found to contribute significantly to litter decomposition (Riemer et al., 1974). Changes in bacterial and fungal nutrient layers are also associated with specific enzyme activities ( $\mathrm{Li}$ et al., 2019). Results from a previously published study determined that bacterial communities that undergo disparate litter nutrient transformation and humus decomposition processes lead to interspecific competition, thus altering bacterial community composition and diversity (Liu et al., 2017). The role that bacterial communities play in the transformation of organic substrates and the release of mineral elements is therefore indispensable (Yang et al., 2018). Additionally, many strains isolated from soil can degrade cellulose (Lopez-Mondejar et al., 2016). Accordingly, understanding characteristics of bacterial communities and associated enzyme activities in litter is crucial when exploring litter decomposition mechanisms.

The response of bacterial communities to environmental factors at different spatial scales remains controversial among researchers. Studies have shown that climate is the key factor for both the global and regional scale regulation of litter decomposition (Rastogi et al., 2012; Bradford et al., 2017). Nutrient content and nutrient availability also play important roles at a local scale (Allison and Vitousek, 2004). At present, research on litter has mainly focused on forest, grassland and other ecological systems, such as the impact of litter decomposition on soil nutrients and microbial communities (Xiangqin et al., 2011). However, studies related to microbial community characteristics and enzyme activities of litter in degraded ecosystems are relatively rare. Specifically, studies on litter phytoremediation in mining areas contaminated with heavy metals have yet to be seriously conducted. Consequently, this remediation approach in these specific areas remains largely unexplored and unresolved.

The Eighteen River tailings dam of the Northern Copper Mine is in Yuanqu County, Shanxi Province, China. In this tailings dam, large-scale mining activities have resulted in an enormous amount of tailings accumulation that has subsequently resulted in severe pollution and damage to the local ecological environment (Oka and Uchida, 2018). Heavy metal contamination in the soil of this copper tailings dam is severe and soil nutrition is poor. Thus, ecological restoration in this mining area is urgently required. Bothriochloa ischaemum is an important phytoremediation species used in copper tailings dams. This perennial herbaceous grass species tolerate warm seasonal temperatures while also being drought tolerant and highly regenerable (Qingan et al., 2006). As phytoremediation a progress, litter accumulates year by year, eventually becoming the primary organic matter source during the succession process of ore soil. Litter is the link between vegetation and soil interface, and it plays an important role in the function of aboveground and belowground ecosystems
(Bani et al., 2018; Tan et al., 2020). Litter decomposition controls both the material and chemical cycles of terrestrial ecosystems (Cotrufo et al., 2015). Therefore, exploring litter decomposition characteristics and associated influencing factors in a copper tailing dam will help provide new insight into understanding the crucial role that litter decomposition plays in nutrient cycling in this region. In this study, we selected three subdams representative of different phytoremediation years as the sampling plots where $B$. ischaemum specimens were collected. We hypothesized that soil and litter properties, litter enzyme activities, as well as bacterial community characteristics varied over different phytoremediation years, while litter properties and enzyme activities rather than soil properties would drive litter bacterial community structures and functions. To test our hypothesis, we conducted this study (i) to compare characteristics of bacterial community structure and diversity in B. ischaemum litter during different phytoremediation years; (ii) to analyze dynamic changes of enzyme activities in $B$. ischaemum litter as phytoremediation progresses; (iii) and to explore the main driving factors that affect bacterial communities and enzyme activities in $B$. ischaemum litter during each recovery stage. By clarifying the relationship between the litter bacterial community and resident environmental factors during different phytoremediation years, the ecological role that litter plays in degraded ecosystems can be further understood. This study also offers a scientific basis for researchers to improve poor quality soil while enhancing the efficiency of ecological restoration in copper tailings areas.

\section{MATERIALS AND METHODS}

\section{Site Description and Soil Sampling}

Construction of the Eighteen River tailings of the Northern Copper Mine $\left(35^{\circ} 15^{\prime} \sim 35^{\circ} 17^{\prime} \mathrm{N}, 118^{\circ} 38^{\prime} \sim 111^{\circ} 39^{\prime} \mathrm{E}\right)$ in the southern region of the Zhongtiao Mountains started in 1969. This region is under the influence of a continental monsoon climate. The average annual temperature is $13.5^{\circ} \mathrm{C}$, while the annual precipitation is $631 \mathrm{~mm}$. Currently, the Eighteen River tailings dam is composed of 16 sub-dams (Jia et al., 2019). The main constituents of the dam comprise of copper tailings and artificial loess. The slope ratio of the dam is 1:6.

Three sub-dams (S523, S536, and S560) that have individually undergone 38,22 , and 5 phytoremediation years, respectively, were selected for sampling. The latitudinal and longitudinal coordinates are $35^{\circ} 26^{\prime} \mathrm{N}$ and $111^{\circ} 66^{\prime} \mathrm{E}$. Top soil samples as well as litter from the soil surface were collected within the B. ischaemum distribution area of each sub-dam, where three replications were made for each sub-dam. Sampling plots were spaced at a distance of between 100 and $120 \mathrm{~m}$. For each replicate, we collected $200 \mathrm{~g}$ of soil and $100 \mathrm{~g}$ of litter samples to measure chemical properties and enzyme activities. A total of 18 litter and soil samples were collected. Samples were sealed in self-sealing plastic bags and placed inside boxes containing ice before being immediately being transported to the lab. Litter samples were then subdivided into two, one stored at $-20^{\circ} \mathrm{C}$ for high-throughput sequencing 
and the other stored at $4^{\circ} \mathrm{C}$ along with soil samples to determine physiochemical properties. Sterile gloves were worn throughout the sampling process to avoid sample contamination.

\section{Chemical Properties and Enzyme Activities of Samples}

The drying method was used to determine soil water content (SWC). An elemental analyzer (vario EL/MACRO cube, Elementar, Hanau, Germany) was used to measure total soil carbon (TC) and total soil nitrogen (TN) content in litter (TC_Litter and TN_Litter, respectively). Soil pH was measured after shaking samples in a soil-water $(1: 2.5 \mathrm{~m} / \mathrm{v})$ suspension for 30 min (Wang et al., 2018). Soil particle size (PS) was measured by using a Mastersizer 3000 laser diffraction particle size analysis instrument (Malvern Co., Ltd., Malvern, United Kingdom). Heavy metal elements, including arsenic (As), cadmium (Cd), copper $(\mathrm{Cu})$, lead $(\mathrm{Pb})$, and zinc $(\mathrm{Zn})$, were measured using Inductively Coupled Plasma-Atomic Emission Spectrometry (iCAP 6000, Thermo Fisher, United Kingdom). Potassium permanganate titration was used to measure catalase. 3,5Dinitrosalicylic acid colorimetry was used to measure sucrase and cellulase, while phenol-sodium hypochlorite colorimetry was used to measure urease. Finally, iodimetry was used to measure polyphenol oxidase.

\section{Techniques Used for DNA Extraction, PCR Amplification and MiSeq Sequencing}

Nine litter samples were initially washed three times in a sterile phosphate buffer solution (PBS: $\mathrm{NaCl}, \mathrm{KCl}, \mathrm{Na}_{2} \mathrm{HPO}_{4}$, and $\left.\mathrm{KH}_{2} \mathrm{PO}_{4}\right)$ before filtering through a sterile membrane filter $(0.2 \mu \mathrm{m}$ pore size) (Millipore, Jinteng, Tianjin, China). These filtered samples, used to extract microbial DNA, were then sealed in sterile centrifuge tubes. The E.Z.N.A. ${ }^{\circledR}$ Soil DNA Kit (Omega Bio-Tek, Norcross, GA, United States) was employed for the extraction of microbial plant and soil DNA under the manufacturer's protocol. The NanoDrop ND-1000 UV-Vis Spectrophotometer (NanoDrop Technologies, Wilmington, DE, United States) was used to quantify extracted DNA. Amplification of the V5-V7 hyper variable region of the 16S rRNA bacterial gene was conducted using primers 799F (5'-AACMGGATTAGATACCCKG-3') and 1193R (5'ACGTCATCCCCACCTTCC-3'). We conducted sequencing at Shanghai Majorbio Bio-pharm Technology (Shanghai, China), applying the MiSeq platform (Illumina, Inc., United States).

\section{Processing of Sequencing Data}

The raw 16S rRNA gene sequencing reads were demultiplexed, quality-filtered by fastp version 0.20 .0 (Chen et al., 2018) and merged by FLASH version 1.2.7 (Magoè and Salzberg, 2011) with the following criteria: (i) the $300 \mathrm{bp}$ reads were truncated at any site receiving an average quality score of $<20$ over a $50 \mathrm{bp}$ sliding window, and the truncated reads shorter than $50 \mathrm{bp}$ were discarded, reads containing ambiguous characters were also discarded; (ii) only overlapping sequences longer than 10 bp were assembled according to their overlapped sequence.
The maximum mismatch ratio of overlap region is 0.2 . Reads that could not be assembled were discarded; (iii) samples were distinguished according to the barcode and primers, and the sequence direction was adjusted, exact barcode matching, 2 nucleotide mismatch in primer matching. Operational taxonomic units (OTUs) with $97 \%$ similarity cutoff were clustered using UPARSE version 7.1, and chimeric sequences were identified and removed (Stackebrandt et al., 1994; Edgar, 2013). The taxonomy of each OTU representative sequence was analyzed by RDP Classifier version 2.2 (Wang et al., 2007) against the silva132/16s_bacteria database using confidence threshold of 0.7 . The bacterial sequences were banked in the National Center for Biotechnology Information (NCBI) database under the Sequence Read Archive (SRA) accession: PRJNA625865.

\section{Statistical Analysis}

Differences in chemical properties among soil, litter and enzyme activities of each sub-dam, which did not comply with the normal distribution, were tested using the Kruskal-Wallis $H$ test in SPSS Statistics version 24.0. Analysis of the microbial community structure was performed using SPSS Statistics version 24.0 and SigmaPlot version 14.0. Spearman's rank correlation coefficient was employed to analyze relationships among environmental factors and microbial community diversity correlation analysis, and Venn diagrams were generated using R3.5.3. Redundancy analysis (RDA) was conducted in Canoco 5.0 (Microcomputer Power, United States).

\section{Bioinformatics Analysis}

Non-metric multidimensional scaling (NMDS) analysis was conducted on the bacterial community structure based on Bray-Curtis Dissimilarity, and ANOSIM was used to analyze inter-group differences. Additionally, variance inflation factor (VIF) analysis was used to eliminate the high collinearity of environmental factors using the "vegan package" in R 3.5.3. We used the interactive platform Gephi to explore and visualize networks (Bastian et al., 2009). phylogenetic investigation of communities by reconstruction of unobserved states (PICRUSt) program was used to predict bacterial community functions based on the KEGG database (Langille et al., 2013), which could obtain the correlated the microbial functional features with the important enzymes. This method analysis was performed using the free online platform of Majorbio Cloud Platform ${ }^{1}$.

\section{RESULTS}

\section{Soil and Litter Physical and Chemical Properties}

The soil TC, TN, C/N, PS, and SWC were increased as phytoremediation years progressed. Moreover, soil TC in S523 was higher than in the other sub-dams dams (i.e., S523, S536, and S560) (Table 1). Litter TC, TN, and $\mathrm{C} / \mathrm{N}$ varied among the three sub-dams. During the early phytoremediation stage, soil As and Cd concentrations were

${ }^{1}$ www.majorbio.com 
TABLE 1 | Soil and litter properties over progressive phytoremediation years.

\begin{tabular}{|c|c|c|c|c|}
\hline \multicolumn{2}{|c|}{ Physical and chemical factors } & \multirow{2}{*}{$\frac{\mathbf{S 5 2 3}}{12.16 \pm 1.67 a}$} & \multirow{2}{*}{$\begin{array}{c}\mathbf{S 5 3 6} \\
6.47 \pm 1.95 b\end{array}$} & \multirow{2}{*}{$\frac{\mathbf{S 5 6 0}}{5.57 \pm 2.07 b}$} \\
\hline Soil & TC_Soil (g/kg) & & & \\
\hline & TN_Soil (g/kg) & $0.28 \pm 0.13$ & $0.24 \pm 0.14$ & $0.22 \pm 0.13$ \\
\hline & C/N_Soil & $53.64 \pm 7.00$ & $30.35 \pm 6.71$ & $28.53 \pm 31.00$ \\
\hline & SWC (\%) & $0.09 \pm 0.02$ & $0.07 \pm 0.03$ & $0.06 \pm 0.03$ \\
\hline & $\mathrm{pH}$ & $8.19 \pm 0.08$ & $8.11 \pm 0.10$ & $8.22 \pm 0.16$ \\
\hline & $\mathrm{PS}(\mu \mathrm{m})$ & $49.03 \pm 12.68$ & $41.30 \pm 10.92$ & $36.07 \pm 5.43$ \\
\hline & As (mg/kg) & $14.71 \pm 1.53 a b$ & $25.44 \pm 9.50 a$ & $4.58 \pm 1.30 b$ \\
\hline & $\mathrm{Cd}(\mathrm{mg} / \mathrm{kg})$ & $6.38 \pm 1.07 a$ & $7.58 \pm 0.83 a$ & $3.19 \pm 0.08 b$ \\
\hline & $\mathrm{Cu}(\mathrm{mg} / \mathrm{kg})$ & $378.18 \pm 43.37 b$ & $347.03 \pm 18.94 b$ & $487.84 \pm 51.10 a$ \\
\hline & $\mathrm{Pb}(\mathrm{mg} / \mathrm{kg})$ & $243.14 \pm 39.00$ & $173.07 \pm 37.91$ & $185.81 \pm 107.93$ \\
\hline & $\mathrm{Zn}(\mathrm{mg} / \mathrm{kg})$ & $87.53 \pm 23.77$ & $72.36 \pm 10.87$ & $51.28 \pm 15.02$ \\
\hline \multirow[t]{3}{*}{ Litter } & TC_Litter (g/kg) & $434.02 \pm 0.88 a b$ & $442.24 \pm 3.36 a$ & $420.80 \pm 1.69 b$ \\
\hline & TN_Litter (g/kg) & $13.28 \pm 1.36 a$ & $4.72 \pm 0.14 c$ & $10.91 \pm 0.78 b$ \\
\hline & C/N_Litter & $32.96 \pm 3.49 c$ & $93.79 \pm 3.15 a$ & $38.73 \pm 2.68 b$ \\
\hline
\end{tabular}

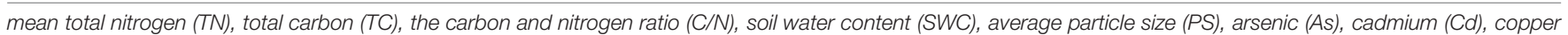
$(\mathrm{Cu})$, lead $(\mathrm{Pb})$ and zinc $(\mathrm{Zn})$. Data are means \pm standard deviation. Significant differences between sites $(P<0.05)$ are represented by letters $(a>b>c)$.

significantly lower than the other periods. In contrast, Cu content was significantly higher during the early phytoremediation stage (Table 1). No significant differences were found in $\mathrm{Pb}$ and $\mathrm{Zn}$ concentrations of all three sub-dams. Litter TC content in S536 was greater than that in S560. Litter TN content in S523 was higher than that in the other sub-dams (Table 1). Furthermore, TC and TN concentrations in litter were greater than a factor of 53.6 and 39.1, respectively, than that in soil (Table 1).

Five litter enzymes exhibited significant differences as phytoremediation years progressed (Table 2). Urease and sucrase in S523 were significantly higher than corresponding values in the other sub-dams. Catalase and polyphenol oxidase in litter of S536 were significantly higher than that corresponding values in S523. Cellulase activity decreased significantly as phytoremediation years progressed (Table 2), while urease activity increased as phytoremediation years progressed (Table 2).

\section{Composition and Diversity of Litter Bacterial Communities}

Illumina high-throughput sequencing was used to analyze the structure and diversity of the $B$. ischaemum litter bacterial communities. A total of 297 OTUs were measured in the

TABLE 2 | Enzyme activities in Bothriochloa ischaemum litter over different phytoremediation years.

\begin{tabular}{lccc}
\hline Enzyme activity & S523 & S536 & S560 \\
\hline Urease $[\mathrm{mg} /(\mathrm{g} \cdot 24 \mathrm{~h})]$ & $2.35 \pm 0.42 \mathrm{a}$ & $0.86 \pm 0.38 \mathrm{~b}$ & $0.36 \pm 0.31 \mathrm{~b}$ \\
Sucrase $[\mathrm{mg} /(\mathrm{g} \cdot 24 \mathrm{~h})]$ & $12.25 \pm 1.22 \mathrm{a}$ & $1.30 \pm 0.19 \mathrm{~b}$ & $2.53 \pm 1.00 \mathrm{~b}$ \\
Catalase $[\mathrm{mg} /(\mathrm{g} \cdot 20 \mathrm{~min})]$ & $1.78 \pm 0.15 \mathrm{~b}$ & $4.02 \pm 0.84 \mathrm{a}$ & $2.16 \pm 0.48 \mathrm{ab}$ \\
Cellulase $[\mathrm{mg} /(\mathrm{g} \cdot 72 \mathrm{~h})]$ & $0.57 \pm 0.09 \mathrm{c}$ & $1.14 \pm 0.12 \mathrm{~b}$ & $1.38 \pm 0.07 \mathrm{a}$ \\
Polyphenol oxidase $(\mathrm{mL} / \mathrm{g})$ & $4.80 \pm 0.84 \mathrm{~b}$ & $5.70 \pm 0.55 \mathrm{a}$ & $5.20 \pm 0.45 \mathrm{ab}$
\end{tabular}

Data are means \pm standard deviation. Different letter cases indicate that the means are significantly different over different phytoremediation years. Significant differences between sites $(P<0.05)$ are represented by letters $(a>b>c)$. three samples, with a total of 15,4893 effective sequences and $5,821,3043 \mathrm{bp}$ and an average length of $376 \mathrm{bp}$. The dominant litter bacteria were Gammaproteobacteria, Actinobacteria, Alphaproteobacteria, Deltaproteobacteria, and Bacteroidia (Figure 1A). At a genus level, the dominant bacteria were Massilia, Sphingomonas, Curtobacterium, Amnibacterium, and Methylobacterium (Figure 1B). The relative abundances of Alphaproteobacteria and Methylobacterium significantly differed among the three sub-dams, with the highest in S523 and the lowest in S536 (Figure 2).

The diversity of bacteria in litter significantly differed for the different phytoremediation years. Litter bacterial community richness was lowest in S523 and highest in S536. The Shannon index of the bacterial community was highest in S523 during the early phytoremediation stage and lowest in the S536 (Table 3). As phytoremediation years progressed, litter bacterial community richness increased but gradually exhibited uneven distribution patterns. Moreover, results from NMDS analysis showed that the bacterial community composition in B. ischaemum litter varied significantly as phytoremediation years progressed $(P<0.05)$ (Figure 3).

\section{Effect of Environmental Factors on Litter Bacterial Diversity}

Litter bacterial community diversity closely correlated to soil physicochemical properties. Soil TC was positively correlated to the Shannon index and negatively correlated to the Simpson index (Figure 4A). Litter $\mathrm{C} / \mathrm{N}$ was significantly negatively correlated to the Shannon index and positively correlated to the ACE index (Figure 4C). Sucrase was significantly positively correlated to the Shannon index and negatively correlated to the Simpson index, the ACE index and the Chaol index. Catalase was negatively correlated to the Shannon index and positively correlated to the Chaol index (Figure 4D). 

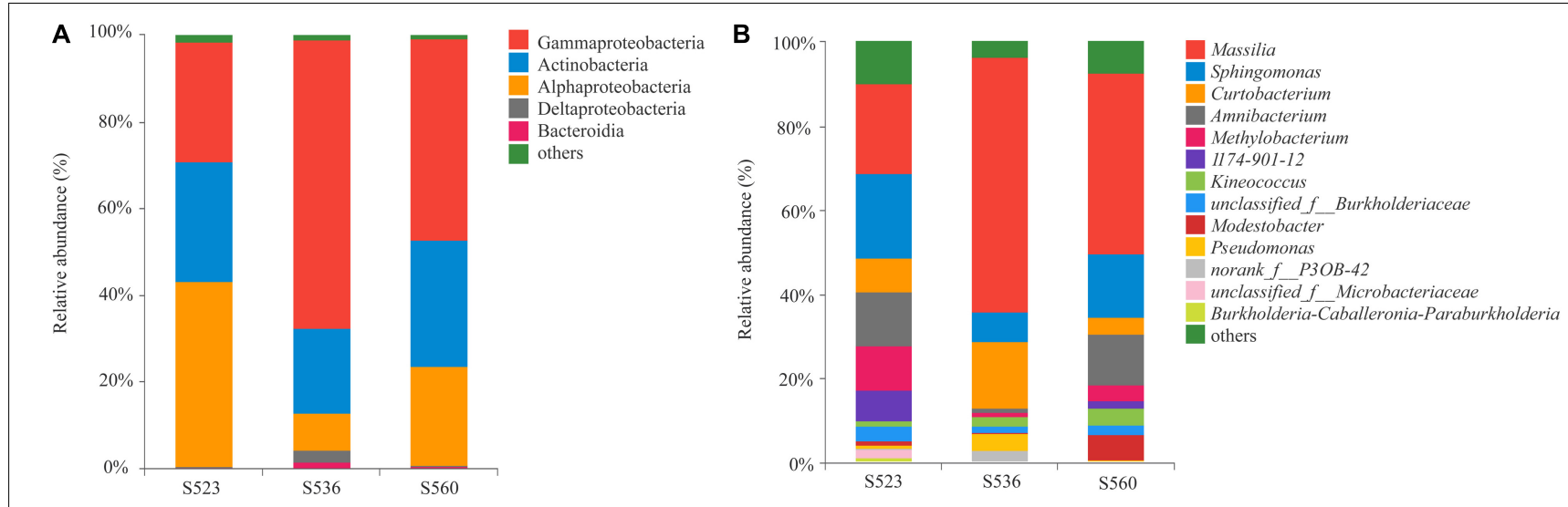

FIGURE 1 | The relative abundance of the litter bacterial community at the class (A) and genus (B) level over different phytoremediation years.

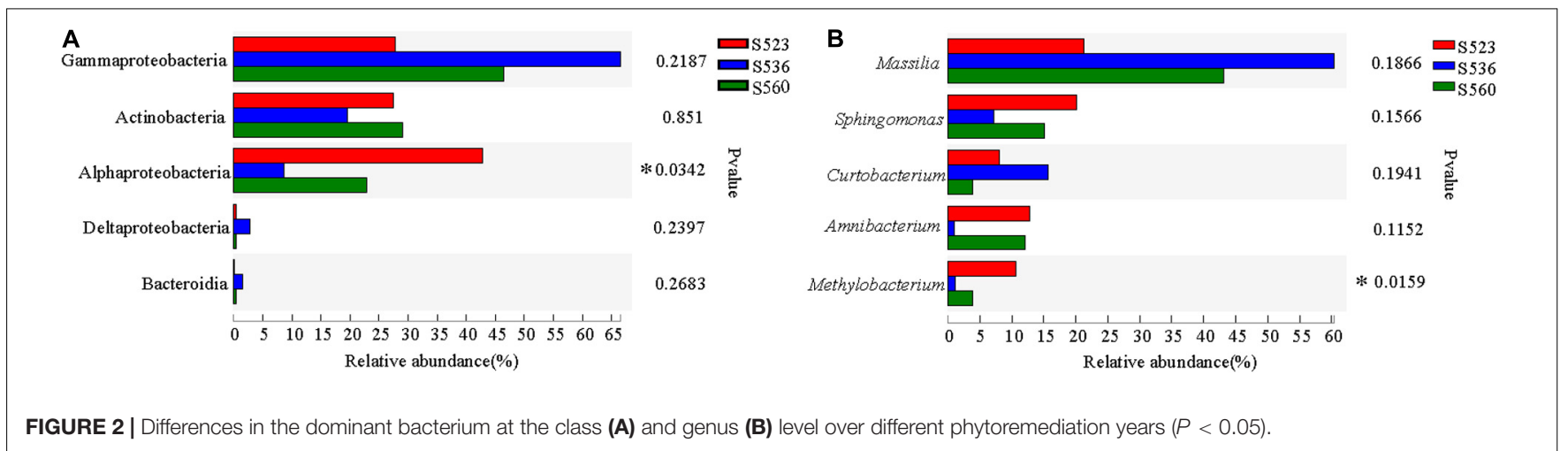

\section{Effect of Litter and Soil Properties on the Bacterial Composition of Litter}

In order to explore the driving factors that are responsible for differences in the bacterial communities of the three sub-dams, RDA was used to analyze the relationships of the dominant bacteria in B. ischaemum litter to soil physicochemical factors, heavy metals, physicochemical litter factors and litters enzyme activities (Figure 5). As shown in Figure 5A, RDA1 and RDA2 explained 71.76 and $9.17 \%$ of the differences in litter bacterial communities, respectively. Soil TN and SWC had the greatest influence on the bacterial community structure in litter (Figure 5A). For heavy metals, $\mathrm{Cd}$ and $\mathrm{Zn}$ had the

TABLE 3 | Richness and diversity indices of the litter bacterial community over different phytoremediation years.

\begin{tabular}{llllll}
\hline Sample number & \multicolumn{5}{c}{ Similarity 97\% } \\
\cline { 2 - 6 } & $\begin{array}{c}\text { Shannon } \\
\text { index }\end{array}$ & $\begin{array}{c}\text { Simpson } \\
\text { index }\end{array}$ & ACE index Chao index Coverage \\
\hline S523 & $3.42 a$ & 0.06 & $160.05 b$ & 157.79 & 99.82 \\
S536 & $2.07 b$ & 0.26 & $223.19 a$ & 199.69 & 99.58 \\
S560 & $2.58 a b$ & 0.20 & $183.06 a b$ & 187.47 & 99.65 \\
\hline
\end{tabular}

Significant differences between sites $(P<0.05)$ are represented by letters $(a>b)$. strongest influence on the bacterial community structure in litter (Figure 5B). For the physicochemical characteristics of litter, TN in litter had a significant impact on the bacterial community structure (Figure 5C). RDA1 and RDA2 accounted for 55.99 and $5.66 \%$ of enzyme activity differences in bacterial communities, respectively (Figure 5D). Sucrase and catalase were strongly correlated to the bacterial community. Catalase

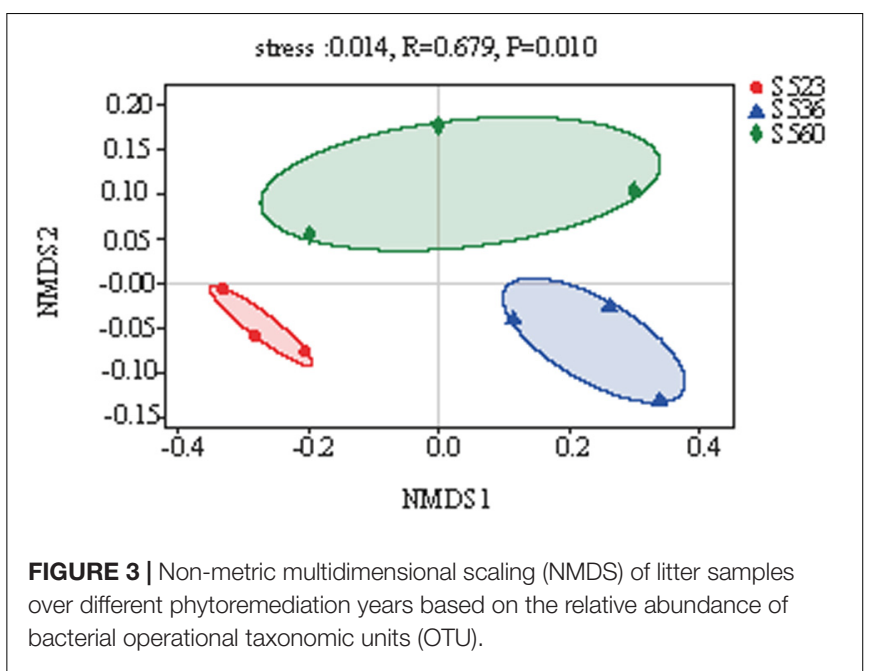




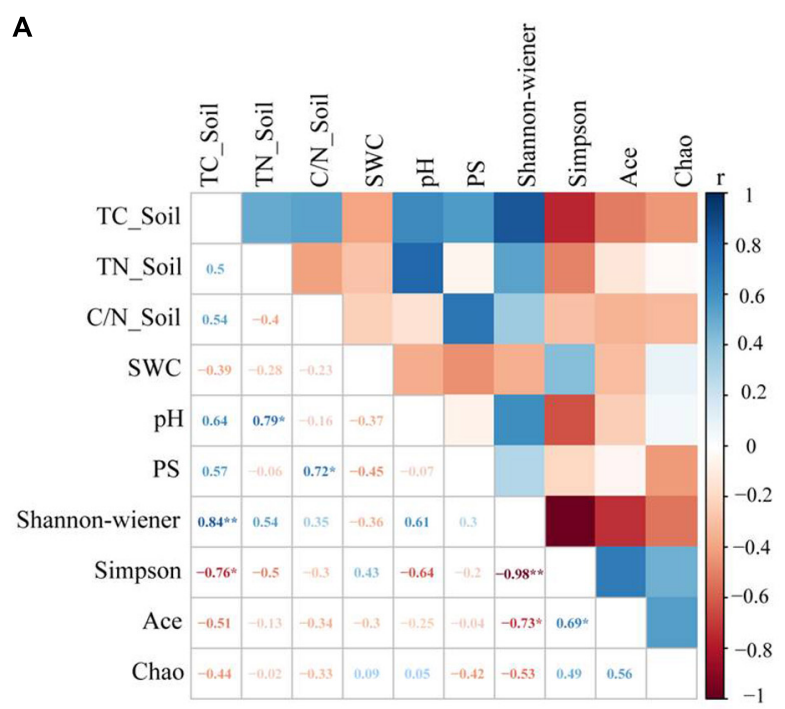

C

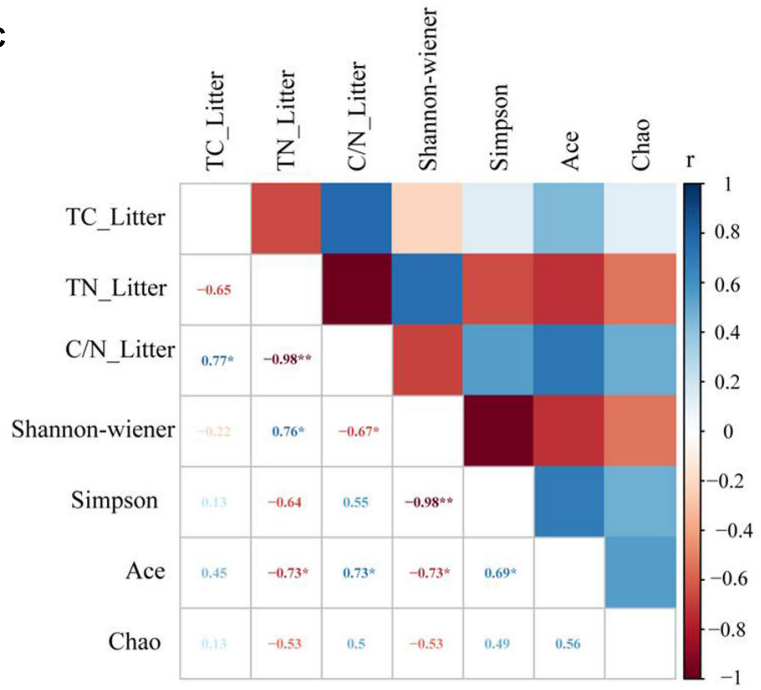

B

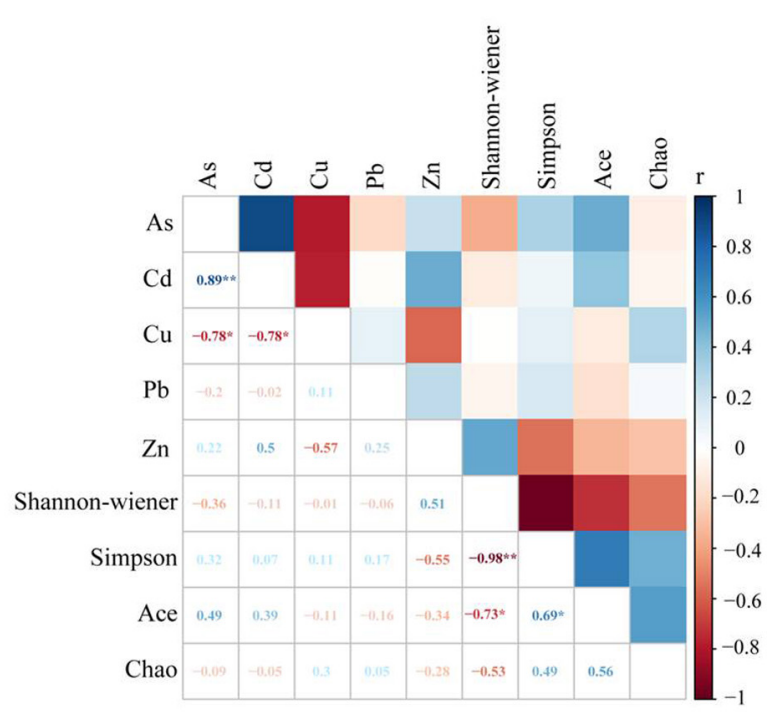

D

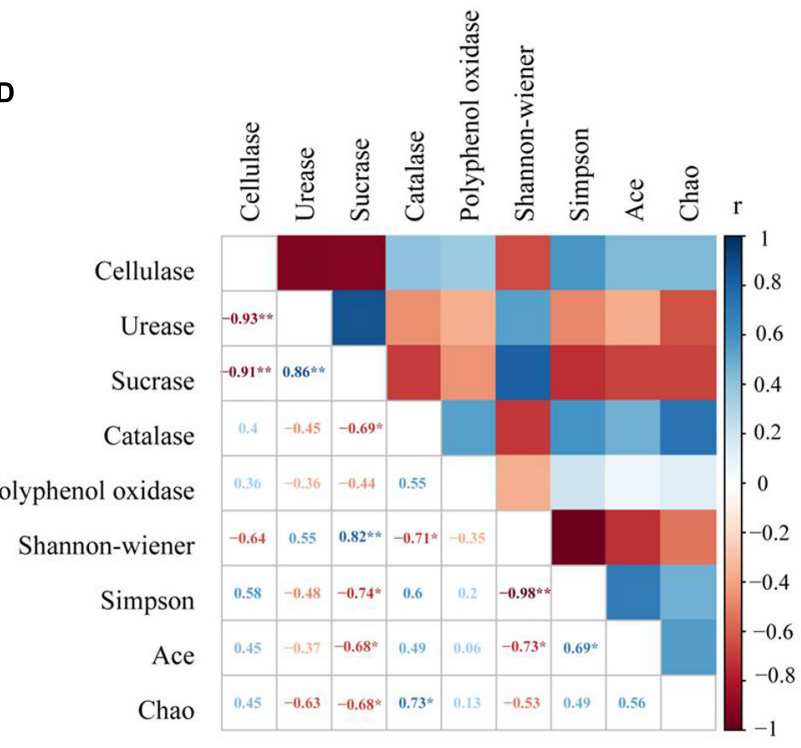

FIGURE 4 | Correlations between environmental factors and bacteria diversity in litter. Environmental factors include soil properties (A), heavy metals (B), litter properties (C), and litter enzyme activities (D). Soil properties include total carbon (TC_Soil), total nitrogen (TN_Soil), the carbon and nitrogen ratio (C/N_Soil), pH, soil water content (SWC) and average particle size (PS). Litter properties include total carbon (TC_Litter), total nitrogen (TN_Litter) and the carbon and nitrogen ratio (C/N_Litter), while litter enzyme activities include cellulase, urease, sucrase, catalase and polyphenol oxidase. ${ }^{\star}$ Correlations are significant at a level of 0.05 (two-tailed); ${ }^{\star \star}$ correlations are significant at a level of 0.01 (two-tailed).

activity had a significant effect on bacterial community structure $(P<0.05)$. Correlation analysis showed that Massilia was negatively correlated to soil TC and SWC and litter TN. Moreover, Massilia had a significant positive correlation to litter $\mathrm{C} / \mathrm{N}$ and sucrase. Sphingomonas was positively correlated to litter $\mathrm{TN}$ and catalase while negatively correlated to litter $\mathrm{C} / \mathrm{N}$ and sucrase. Methylobacterium was positively correlated to TC in soil and $\mathrm{TN}$ and catalase in litter while negatively correlated to $\mathrm{C} / \mathrm{N}$ and sucrase in litter (Figure 6A). The network diagram revealed that Methylorosula, Jatrophihabitans, Belnapia, Acidiphilium, and Bdellovibrio, which had relatively higher betweenness centrality, played important roles in bacterial community interactions at a genus level (Figure 6B). These keystone microbes can be generally defined as those species that have a disproportionate influence on ecosystems regardless of abundance, and they are crucial in the maintenance of the stability and the function of ecosystems as well as the resistance of system disturbances.

\section{Functional Characteristics of Litter Bacterial Communities}

This study used PICRUSt to identify gene encoding enzymes associated with starch, cellulose, hemicellulose and lignin (Figure 7). Encoding gene abundance of cellulase and lignin were 


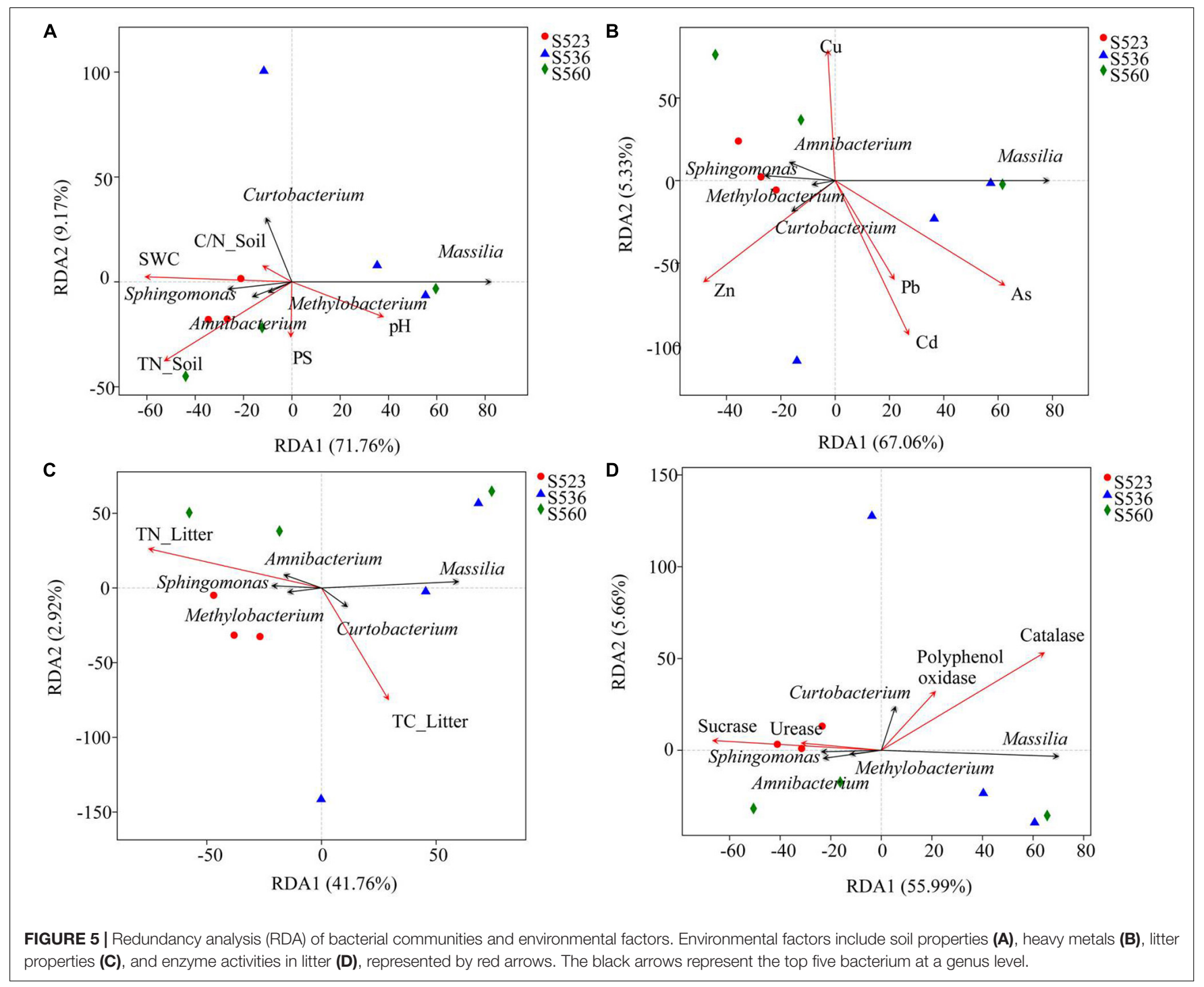

higher than that of amylase and hemicellulase. The abundance of cellulase and hemicellulase encoding genes was the highest in S523. Except for the encoding genes alpha-amylase and catalase, the abundance of other genes was the lowest in S536. The relative abundance of the functional encoding genes xylan 1,4beta-xylosidase and catalase significantly differed in the three sub-dams (Figure 7). The relative abundance of functional the encoding gene catalase was the highest in S536, which was consistent with results from catalase activity (Table 2).

\section{DISCUSSION}

\section{Soil and Plant (B. ischaemum) Litter Characteristics}

Physical and chemical soil properties are accepted as two important soil quality indices. Results from this study showed that over a progressive increase in remediation years, both soil carbon and litter nitrogen reached their maximum values during the latter phytoremediation stage (Table 1), which was consistent with previously published studies (Jia et al., 2017, 2018a; Wang et al., 2018). This result also supported our hypothesis. The main reason for this is that surface litter can add humus to the soil, effectively improving both the soil nutrient content and the soil quality (Li et al., 2015). Accumulation of $\mathrm{Cu}$ was the most severe during the early phytoremediation stage, while it significantly decreased during the latter phytoremediation stage. The reason for this is that $B$. ischaemum possesses a certain remediation function to extirpate heavy metals in soil, especially through its strong enrichment of Cr (Jia et al., 2018b). A previous study showed that litter from new sheathes and stems had lower nitrogen concentrations compared to older sheathes and stems (Liao et al., 2010). In our study, litter TN was relatively low in S536 compared to that in the other subdams (Table 1), which may have resulted from the fact that most litter in S536 had newly generated, while litter in the other sub-dams was relatively old. The decomposition process of litter by microbial activity is essentially a biochemical enzymatic 


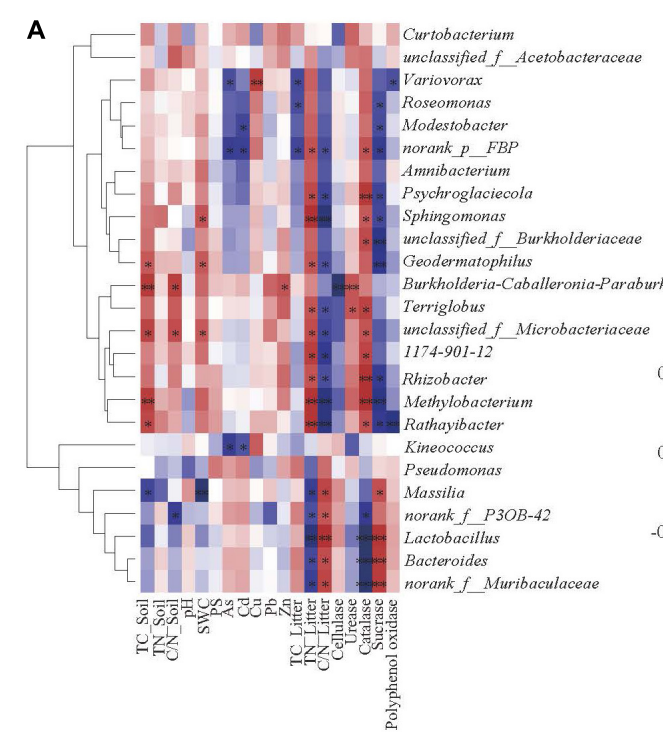

B

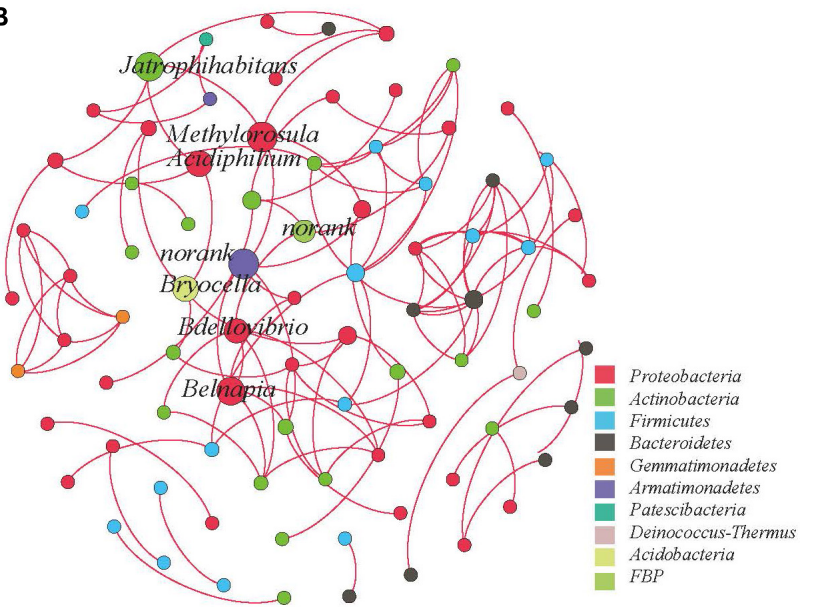

FIGURE 6 | Correlation heat map of the top 25 genus (A) and soil and vegetation properties. The $X$ and $Y$ axis represent environmental factors and phyla, respectively. $R$ is shown in different colors, where the right side of the legend is the color range of the different $r$ values. ${ }^{*} P<0.05$; ${ }^{* \star} P<0.01$. The Co-occurrence network of bacterial taxa in litter. Nodes represent bacteria genus (B), while red edges represent positive connections between species pairs, respectively.

decomposition process. During the early phytoremediation stage, cellulase predominated in litter (Table 2). This indicated that hemicellulose and cellulose were the two major carbon sources

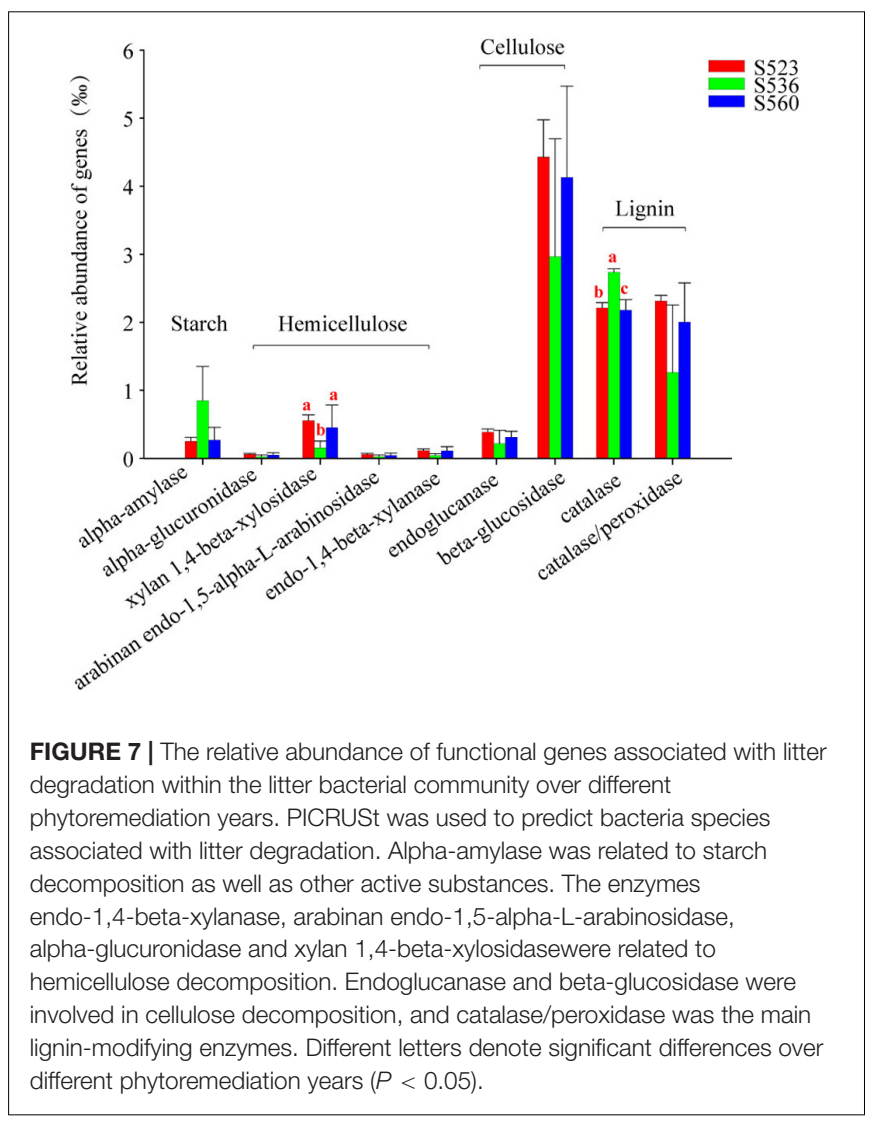

available to microorganisms during this stage (Schneider et al., 2012). Later, cellulase activity decreased significantly. This could have resulted from a gradual increase in litter organic matter as phytoremediation progressed. Also, the preferential use of easily decomposable cellulose by microorganisms could have led to a decrease in the utilization of cellulose, which subsequently led to a decrease in enzyme activities. On the other hand, cellulase may have derived primarily from fungi during the early litter decomposition stage. By the latter phytoremediation stage, bacteria would gradually predominate (Elisashvili et al., 2008). Catalase is an important oxidoreductase that is directly involved in both material transformation and energy flow. It is associated with organic matter content and can reflect the intensity of microbial processes (Lu et al., 2002). In this study, catalase reached its maximum value during the intermediate phytoremediation stage (Table 2), which indicated that bacteria played a relatively active role in litter decomposition during this intermediate stage.

\section{Litter Bacterial Community Structure and Diversity}

This study found a significant difference in the relative abundance of Alphaproteobacteria and Methylobacterium in the three sub-dams, where S523 yielded the highest values and S536 yielded the lowest (Figure 2), which supported the hypothesis. The genus Methylobacterium belongs to the class Alphaproteobacteria. Taylor et al. (2012) reported 12 bacterial genera that were able to degrade sulfonated lignin, which mainly belonged to the phylum Actinobacteria and the class Alphaproteobacteria. Previous studies had shown that Proteobacteria belongs to either symbiotic or $r$-selected species, possessing clear advantages in ecological niche competitive 
behavior under nutrient-rich conditions. Soil and litter had the highest $\mathrm{N}$ content in S523. Moreover, Methylobacterium was significantly and positively correlated to total C in soil (TC_Soil) and total $\mathrm{N}$ in litter (TN_Litter) (Figure 6A). These results indicated that Methylobacterium is predisposed to predominate in nutrient-rich regions. The bacterial community composition in $B$. ischaemum litter exhibited significant differences during different phytoremediation years (Figure 3), which was similar to findings from Xu et al. (2020). Differences in soil physical and chemical properties during different phytoremediation years may affect litter decomposition rates, resulting in different litter degradation stages (Suseela et al., 2014). Moreover, this may be one reason that litter bacterial communities in our sample plots exhibited significant differences over different restoration years. Additionally, litter bacterial community richness was low, while bacterial community distribution was relatively uniform during the early phytoremediation stage. Although bacterial community richness in litter increased, it gradually exhibited uneven distribution patterns over progressive phytoremediation years (Table 3 and Figure 3). This may have resulted from an improvement in soil nutrients that consequently promoted an increase in plant diversity. This condition would gradually alter physical and chemical litter properties, consequently changing bacterial community richness (Urbanova et al., 2015).

\section{Effects of Environmental Factors on Litter Bacterial Community Characteristics}

Studies have shown that litter quality effects both community decomposition and ecosystem processes (Prescott, 2010). Results from correlation analysis showed a significant correlation between soil TC and litter TN along with bacterial community diversity (Figure 4). This was a little bit different from the hypothesis. This indicated that changes in soil and litter nutrients will have an impact microbial community composition, where nutrient availability will consistently be positively correlated to microbial diversity (Yan et al., 2010). Moreover, diversity indices revealed a significant correlation between sucrase and catalase. The Shannon and Simpson indices were used to characterize soil and litter nutrients, while richness indices were best at characterizing soil enzyme activities in this copper tailings dam (Figure 4). The reason for this is that bacterial community diversity in litter is impacted by various aboveground compositional and conditional factors associated with biodiversity, while litter decomposition rates are also closely correlated to soil enzyme activities (Crumsey et al., 2015; Müller et al., 2016; Liu et al., 2017). Moreover, RDA showed that litter TN and catalase activity significantly affected bacterial community structure (Figure 5), which supported our hypothesis. Given that the behavior of different microbial populations will differ, changes in litter chemical composition and structure will result in the ecological succession of microbial populations during litter decomposition processes. Moreover, some studies have shown that soil moisture may also affect litter decomposition. In an earlier study (Lauber et al., 2009), pH was shown to be the key determining factor for bacterial composition and diversity within a localized soil layer. However, the bacterial community response to environmental factors at different spatial scales remains contentious among researchers. Within ecosystems, both bacterial community growth and activity are primarily impacted by alterations in plant litter and root exudates (Bainard et al., 2016). In our study, the effect of soil $\mathrm{pH}$ was not obvious, which could have been due to the alkalinity of our three sub-plots, for which no significant differences were observed. In general, litter properties were the primary factors that affected litter bacterial community characteristics in our study, particularly $\mathrm{N}$ content.

\section{Primary Driving Factors Impacting Litter Bacterial Functional Groups}

In this study, Massilia and Sphingomonas had the highest overall abundance, while Massilia was significantly negatively correlated to soil TC and litter TN (Figure 6A). This may be due to the wide distribution of Massilia and its strong environmental adaptability. This genus can synthesize a variety of secondary metabolites and enzymes as well as engage in a variety of functions, such as those related to heavy metal resistance (Yang et al., 2019). Thus, we speculated Massilia can potentially be applied to soil remediation and improvement measures. Moreover, our study found that Sphingomonas was positively correlated to litter $\mathrm{TN}$ and negatively correlated to sucrase (Figure 6A). Using PICRUSt, we found genes encoded with cellulase, hemicellulase and lignin-modifying enzymes in litter bacterial communities, demonstrating the critical potential that bacterial communities possess in litter decomposition (Figure 7). The relative abundance of functional genes encoded with catalase was highest in S536, which could be indicative of the high heavy metal tolerance of Sphingomonas (Liu et al., 2017). Additionally, Sphingomonas predominates within alkaline environments under organic pollution, and its metabolic capacity is high (Fredrickson et al., 1995). It is important to note that functional gene distribution is only predictive of the metabolic potential and the ecological function of a bacterial community. In other words, functional gene distribution is not reflective of "real" metabolic activities and ecological functions of bacterial communities (Liang et al., 2019). Additionally, some studies have reported on the differences between functional gene abundance and gene expressions (Hollister et al., 2010; Ossola et al., 2017). Therefore, functional bacterial characteristics in litter decomposition as well as gene expression and associated regulations must be further investigated in future studies.

In brief, our results suggest that bacterial community play a crucial role in the degradation of litters and litter properties can influence the degradation of litters. However, one limitation of this work is that we did not cover the different stages of litter degradation. In the process of litter degradation, the chemistry of the organic substrate continuously changes, which will lead to the change of microbial community structure (Berg and McClaugherty, 2003). In addition, the climate change is also one of the main factors affecting litter degradation (Liang et al., 2019). Future studies will need to take into account the changes in microbial community structure and function at different degradation of the B. ischaemum litter. Such studies 
will further strengthen our understanding of the relationship between the microbial community structure and function and litter decomposition in the context of heavy metal contamination and is critically important to understand the circulation of substances in copper tailings dams.

\section{DATA AVAILABILITY STATEMENT}

The datasets presented in this study can be found in online repositories. The names of the repository/repositories and accession number(s) can be found below: https://www.ncbi.nlm. nih.gov/, PRJNA625865.

\section{AUTHOR CONTRIBUTIONS}

TJ conceived and designed the experiments and wrote the manuscript. YW performed the experiments.

\section{REFERENCES}

Allison, S. D., and Vitousek, P. M. (2004). Extracellular enzyme activities and carbon chemistry as drivers of tropical plant litter decomposition. Biotropica 36, 285-296. doi: 10.1646/03180

Bainard, L. D., Hamel, C., and Gan, Y. (2016). Edaphic properties override the influence of crops on the composition of the soil bacterial community in a semiarid agroecosystem. Appl.ied Soil Ecol. 105, 160-168. doi: 10.1016/j.apsoil. 2016.03.013

Bani, A., Pioli, S., Ventura, M., Panzacchi, P., Borruso, L., Tognetti, R., et al. (2018). The role of microbial community in the decomposition of leaf litter and deadwood. Appl. Soil Ecol. 126, 75-84. doi: 10.1016/j.apsoil.2018.02.017

Bastian, M., Heymann, S., and Jacomy, M. (2009). "Gephi: an open source software for exploring and manipulating networks," in Proceeding of the Third International AAAI Conference on Weblogs And Social Media. (San Jose).

Berg, B., and McClaugherty, C. (2003). Plant Litter: Decomposition, humus formation and carbon sequestration, second ed. Berlin: Springer-Verlag.

Bradford, M. A., Veen, G. F. C., Bonis, A., Bradford, E. M., Classen, A. T., Cornelissen, J. H. C., et al. (2017). A test of the hierarchical model of litter decomposition. Nat. Ecol. Evol. 1, 1836-1845.

Chen, S., Zhou, Y., Chen, Y., and Gu, J. (2018). fastp: an ultra-fast all-in-one FASTQ preprocessor. Bioinformatics 34, i884-i890.

Cotrufo, M. F., Soong, J. L., Horton, A. J., Campbell, E. E., Haddix, M. L., Wall, D. H., et al. (2015). Formation of soil organic matter via biochemical and physical pathways of litter mass loss. Nat. Geosci. 8:776. doi: 10.1038/ngeo2520

Crumsey, J. M., Capowiez, Y., Goodsitt, M., Larson, S., Le Moine, J. M., Bird, J. A., et al. (2015). Exotic earthworm community composition interacts with soil texture to affect redistribution and retention of litter-derived $\mathrm{C}$ and $\mathrm{N}$ in northern temperate forest soils. Biogeochemistry 126, 379-395. doi: 10.1007/ s10533-015-0164-6

Edgar, R. C. (2013). UPARSE: highly accurate OTU sequences from microbial amplicon reads. Nat. Methods 10, 996-998.

Elisashvili, V., Kachlishvili, E., and Penninckx, M. (2008). Effect of growth substrate, method of fermentation, and nitrogen source on lignocellulosedegrading enzymes production by white-rot basidiomycetes. J. Ind. Microbiol. Biotechnol. 35, 1531-1538. doi: 10.1007/s10295-008-0454-2

Fredrickson, J. K., Balkwill, D. L., Drake, G. R., Romine, M. F., Ringelberg, D. B., and White, D. C. (1995). Aromatic-degrading Sphingomonas isolates from the deep subsurface. Appl. Environ. Microbiol. 61, 1917-1922. doi: 10.1128/aem.61. 5.1917-1922.1995

Hollister, E. B., Schadt, C. W., Palumbo, A. V., and Boutton, T. W. (2010). Structural and functional diversity of soil bacterial and fungal communities following woody plant encroachment in the southern Great Plains. Soil Biol. Biochem. 42, 1816-1824. doi: 10.1016/j.soilbio.2010.06.022
BC contributed new reagents. All authors read and approved the manuscript.

\section{FUNDING}

This study was financially supported by the National Natural Science Foundation of China (No. 31600308); a fund from the Shanxi "1331 Project," China (Ecological restoration of damaged soil system), Shanxi Province, namely, the Science Foundation for Excellent Young Scholars (No. 201901D211196); the Scientific and Technological Innovation Programs of Higher Education Institutions in Shanxi (No. 2019L0005); the Shanxi Province Graduate Education Innovation Project (Nos. 2019 SY029 and 2020SY036); the Shanxi Province Foundation for Returnees (No. 2016-006); and the Higher Education Institution Project of Shanxi Province: Ecological Remediation of Soil Pollution Disciplines Group (No. 20181401).

Jia, T., Cao, M., and Wang, R. (2018a). Effects of restoration time on microbial diversity in rhizosphere and non-rhizosphere soil of Bothriochloa ischaemum. Int. J. Environm. Res. Public Health 15:2155. doi: 10.3390/ijerph1510 2155

Jia, T., Cao, M., Jing, J., Liu, J., and Chai, B. (2017). Endophytic fungi and soil microbial community characteristics over different years of phytoremediation in a copper tailings dam of Shanxi. China. Sci. Total Environ. 574, 881-888. doi: 10.1016/j.scitotenv.2016.09.161

Jia, T., Guo, T., Cao, M., and Chai, B. (2018b). Effects of heavy metals on phyllosphere and rhizosphere microbial community of Bothriochloa ischaemum. Appl. Sci. 8:1419. doi: 10.3390/app8091419

Jia, T., Wang, R., and Chai, B. (2019). Effects of heavy metal pollution on soil physicochemical properties and microbial diversity over different reclamation years in a copper tailings dam. J. Soil Water Conserv. 74, 439-448. doi: 10.2489/ jswc.74.5.439

Langille, M. G., Zaneveld, J., Caporaso, J. G., McDonald, D., Knights, D., Reyes, J. A., et al. (2013). Predictive functional profiling of microbial communities using 16S rRNA marker gene sequences. Nat. Biotechnol. 31, 814-821. doi: $10.1038 /$ nbt. 2676

Lauber, C. L., Hamady, M., Knight, R., and Fierer, N. (2009). Pyrosequencing-based assessment of soil $\mathrm{pH}$ as a predictor of soil bacterial community structure at the continental scale. Appl. Environ. Microbiol. 75, 5111-5120. doi: 10.1128/aem. 00335-09

Li, J., Liu, F., and Zhou, X. M. (2015). Effects of different reclaimed scenarios on soil microbe and enzyme activities in mining areas. Environ. Sci. 36, 1836-1841.

Li, Y., Nie, C., Liu, Y., Du, W., and He, P. (2019). Soil microbial community composition closely associates with specific enzyme activities and soil carbon chemistry in a long-term nitrogen fertilized grassland. Sci. Total Environ. 654, 264-274. doi: 10.1016/j.scitotenv.2018.11.031

Liang, T., Yang, G., Ma, Y., Yao, Q., Ma, Y., Ma, H., et al. (2019). Seasonal dynamics of microbial diversity in the rhizosphere of Ulmus pumila L. var. sabulosa in a steppe desert area of Northern China. PeerJ. 7:e7526. doi: 10.7717/peerj.7526

Liao, C., Tang, X., Chen, X., Li, B., and Luo, Y. (2010). Nitrogen dynamics of aerial litter of exotic Spartina alterniflora and native Phragmites australis. Biodiv. Sci. $18,631-637$.

Liu, J., Li, C., Jing, J., Jia, T., Liu, X., Wang, X., et al. (2017). Composition and environmental adaptation of microbial community in shibahe copper tailing in zhongtiao mountain in Shanxi. Environ. Sci. 38, 318-326.

Lopez-Mondejar, R., Zuhlke, D., Becher, D., Riedel, K., and Baldrian, P. (2016). Cellulose and hemicellulose decomposition by forest soil bacteria proceeds by the action of structurally variable enzymatic systems. Sci. Rep. 6:25279.

Lu, P., Guo, J., and Zhu, L. (2002). Soil catalase activity of main plant communities in Leymus chinensis grassland in northeast China. Ying Yong Sheng Tai Xue Bao $13,675-679$. 
Magoè, T., and Salzberg, S. L. (2011). FLASH: fast length adjustment of short reads to improve genome assemblies. Bioinformatics 27, 2957-2963.

Müller, D. B., Vogel, C., Bai, Y., and Vorholt, J. A. (2016). The plant microbiota: systems-level insights and perspectives. Ann. Rev. Genet. 50, 211-234. doi: 10.1146/annurev-genet-120215-034952

Oka, M., and Uchida, Y. (2018). Heavy metals in slag affect inorganic $\mathrm{N}$ dynamics and soil bacterial community structure and function. Environ. Pollut. 243, 713-722. doi: 10.1016/j.envpol.2018.09.024

Ossola, A., Aponte, C., Hahs, A. K., and Livesley, S. J. (2017). Contrasting effects of urban habitat complexity on metabolic functional diversity and composition of litter and soil bacterial communities. Urb. Ecosyst. 20, 595-607. doi: 10.1007/ s11252-016-0617-2

Ostaszewski, P., and Nissen, S. (1988). Effect of hyperglucagonemia on whole-body leucine metabolism in immature pigs before and during a meal. Am. J. Physiol. 254, E372-E377.

Prescott, C. E. (2010). Litter decomposition: what controls it and how can we alter it to sequester more carbon in forest soils? Biogeochemistry 101, 133-149. doi: 10.1007/s10533-010-9439-0

Qingan, F. A. N., Chunhua, P., Jianmin, Z., and Feng, Z. (2006). Bothriochloa ischaemum grassland resource in Shanxi and its sustainable utilization. J. Shanxi Univ. 29, 432-435.

Rastogi, G., Sbodio, A., Tech, J., Suslow, T. V., Coaker, G. L., and Leveau, J. H. J. (2012). Leaf microbiota in an agroecosystem: spatiotemporal variation in bacterial community composition on field-grown lettuce. ISME J. 6, 1812-1822. doi: 10.1038 /ismej.2012.32

Riemer, J., Mayer, C. J., and Ulbrecht, G. (1974). Determination of membrane potential in smooth muscle cells using microelectrodes with reduced tip potential. Pflugers Arch. 349, 267-275. doi: 10.1007/bf00592454

Schneider, T., Keiblinger, K. M., Schmid, E., Sterflinger-Gleixner, K., Ellersdorfer, G., Roschitzki, B., et al. (2012). Who is who in litter decomposition? Metaproteomics reveals major microbial players and their biogeochemical functions. ISME J. 6, 1749-1762. doi: 10.1038/ismej.2012.11

Song, Y., Gu, X. R., Yan, H. Y., Mao, W. T., Wu, X. L., and Wan, Y. X. (2014). Dynamics of microbes and enzyme activities during litter decomposition of Pinus massoniana forest in mid-subtropical area. Environ. Sci. 35, 1151-1158.

Stackebrandt, E., Goebel, B. M., Goebal, B. M, Goebel, B., Stackerbrandt, E., Göbel, S. (1994). Taxonomic note: a place for DNA-DNA reassociation and 16s rRNA sequence analysis in the present species definition in bacteriology. Int. J. System. Bacteriol. 44, 846-849. doi: 10.1099/00207713-44-4-846

Suseela, V., Tharayil, N., Xing, B. S., and Dukes, J. S. (2014). Warming alters potential enzyme activity but precipitation regulates chemical transformations in grass litter exposed to simulated climatic changes. Soil Biol. Biochem. 75, 102-112. doi: 10.1016/j.soilbio.2014.03.022
Tan, X., Machmuller, M. B., Cotrufo, M. F., and Shen, W. (2020). Shifts in fungal biomass and activities of hydrolase and oxidative enzymes explain different responses of litter decomposition to nitrogen addition. Biol. Fertility Soils 56, 423-438. doi: 10.1007/s00374-020-01434-3

Taylor, C. R., Hardiman, E. M., Ahmad, M., Sainsbury, P. D., Norris, P. R., and Bugg, T. D. (2012). Isolation of bacterial strains able to metabolize lignin from screening of environmental samples. J. Appl. Microbiol. 113, 521-530. doi: 10.1111/j.1365-2672.2012.05352.x

Urbanova, M., Snajdr, J., and Baldrian, P. (2015). Composition of fungal and bacterial communities in forest litter and soil is largely determined by dominant trees. Soil Biol. Biochem. 84, 53-64. doi: 10.1016/j.soilbio.2015.02.011

Wang, Q., Garrity, G. M., Tiedje, J. M., and Cole, J. R. (2007). Naive Bayesian classifier for rapid assignment of rRNA sequences into the new bacterial taxonomy. Appl. Environ. Microbiol. 73, 5261-5267.

Wang, R. H., Jia, T., Cao, M. W., and Chai, B. F. (2018). Characteristics of soil physicochemical properties and enzyme activities over different reclaimed years in a copper tailings dam. Environ. Sci. 39, 3339-3348.

Xiangqin, X. U., Zhihua, L. I. N., and Huili, C. (2011). Effects of litter composition on soil organisms: A review. Chinese J. Ecol. 30, $1258-1264$.

Xu, M., Lu, X., Xu, Y., Zhong, Z., Zhang, W., Ren, C., et al. (2020). Dynamics of bacterial community in litter and soil along a chronosequence of Robinia pseudoacacia plantations. Sci. Total Environ. 703:135613. doi: 10.1016/j. scitotenv.2019.135613

Yan, H., Gu, X., and Shen, H. (2010). Microbial decomposition of forest litter: A review. Chin. J. Ecol. 29, 1827-1835.

Yang, E., Cui, D., and Wang, W. (2019). Research progress on the genus Massilia. Microbiol. Chin. 46, 1537-1548.

Yang, F., Wu, J., Zhang, D., Chen, Q., Zhang, Q., and Cheng, X. L. (2018). Soil bacterial community composition and diversity in relation to edaphic properties and plant traits in grasslands of southern China. Appl. Soil Ecol. 128, 43-53. doi: 10.1016/j.apsoil.2018.04.001

Conflict of Interest: The authors declare that the research was conducted in the absence of any commercial or financial relationships that could be construed as a potential conflict of interest.

Copyright $\odot 2020$ Jia, Wang and Chai. This is an open-access article distributed under the terms of the Creative Commons Attribution License (CC BY). The use, distribution or reproduction in other forums is permitted, provided the original author(s) and the copyright owner(s) are credited and that the original publication in this journal is cited, in accordance with accepted academic practice. No use, distribution or reproduction is permitted which does not comply with these terms. 